giant in the urban politics and public administration fields. Accordingly, he was named the first recipient of the Urban Politics Section's Career Achievement Award in 1988 , and was also named the recipient of the APSA's John Gaus Award in 1991. One is less impressed by the sheer volume of his published work than by its extraordinary impact. Several of his articles became classics in the political science, public administration, and urban politics literatures, and were reprinted frequently in readers. Indeed, one of his books, The Polity (1962) was edited by Charles Press, who recognized the importance of collecting some of Norton's most influential work into one volume.

Norton's training in political theory and his background as a practicing public administrator are twin threads binding his work into a coherent whole. He understood that politics infuses all endeavors, including especially those activities undertaken by anyone claiming expertise, neutral competence, and objective knowledge. He understood that policies must reflect a balance between reasoned thinking and democratic processes. His enduring intellectual contribution and influence was to convince us all to be distrustful of reformers who claim simple answers-a compelling legacy to leave to practitioners of a discipline born of reform.

Of his many seminal articles in public administration, two particularly stand out. In a famous article published in 1949, "Power and Administration," he brilliantly dismembered the claims that there was a "science" of administration. He proposed, instead, that divorced from power, administration necessarily became an empty vessel:

There is no more forlorn spectacle in the administrative world than an agency and a program possessed of statutory life, armed with executive orders, sustained in the courts, yet stricken with paralysis and deprived of power. An object of contempt to its enemies and despair to its friends.

Lest anyone conclude his trenchant critique could be put in the service of a reactionary opposition to expertise and public administration per se, three years later he published a seminal article in the APSR ("Bureaucracy and Constitutionalism") that demonstrated how the administrative state fit firmly within the American constitutional tradition.

At a time when the study of urban government remained within the grasp of a normative tradition inherited from the Progressive Era, Norton was enormously influential in bringing politics into the literature-indeed, it may be said that he helped "father" the urban politics field, as it is currently defined. In his famous article, "The Local Community as an Ecology of Games," he cut right through the elitist-pluralist debate by proposing that local politics had a life of its own that could not necessarily be understood as the outcome of rational, calculated actions by individuals. In other words, he suggested, perhaps no one governed the city; our analytical task was, therefore, not to study the behavior of individuals, but to understand how the system as a whole operated. In his second book, The Unwalled City (1972) and in several articles, Norton explored the economic and political interdependence of urban governments years before other scholars began to appreciate how the citizens and governments of metropolitan areas were irretrievably locked into a shared fate. He asked penetrating questions about the possibilities of citizenship in a polity fractured by artificial political boundaries. Those questions now occupy scholars studying urban politics more than any other.

In his last few years Norton became concerned that public administration and the study of cities had lost all ethical moorings. In his Gaus lecture and in recent articles, he convincingly made the case for a system of social accounts that could be used to hold governments accountable. He became a sort of missionary, buttonholing friends and colleagues at conventions and in panel rooms. We can only hope that this compelling idea, like his earlier intellectual contributions, will survive him and influence the work of the next generation of scholars. One thing is sure: professional conferences will not be as interesting without his presence.

Those who knew him well will agree that Norton's greatest contribution is as a role model for others, particularly those in academia, whatever their field of specialization. Four aspects of his overall performance are particularly important to note in context. He was, first of all, an utterly honest and straightforward person-he "called them as he saw them," often to the discomfiture of those responsible for the conditions under discussion. Second, although he was a voracious reader, with an astonishingeven dismaying - capacity to recall who had said what, where, and why, few persons in academic life were as aware as he of real world constraints, or as competent in dealing with them. Third, he took a great interest in the work of younger scholars, whatever the field, and he went to considerable lengths to promote the careers of younger persons whose work he found useful and interesting-both of us are prime beneficiaries of this characteristic. Fourth, and most important of all, although he loved a good argument and hated to lose (he would fight like a tiger in any substantive discussion-whether in a chance encounter in the hallway, at a department meeting, or at an APSA panel-utterly disregarding the status, and sometimes the sensitivities, of those involved), yet when the argument ended, there were never any hard feelings or recriminations, whatever might have been said in the heat of battle-a trait perhaps made easier by the infrequency with which he "lost." In combination, these attributes contributed greatly to Norton's value as a friend, a scholar, a teacher, and a colleague.

Eugene J. Meehan

Dennis R. Judd

University of Missouri-St. Louis

\section{Grant McConnell}

One of the preeminent political scientists of mid-century, Grant McConnell, died at his home in Bonny Doon, California, on Sep- 
tember 27, 1993, at age 78 . Best known as a powerful and influential critic of the dominant role of private interest groups in American politics, Grant is revered today as a visionary in the field of environmental politics and a seminal figure in the study of American political development.

Grant was born on June 27, 1915, in Portland, Oregon, where he grew up. In his youth he skied competitively, spent his summers in the forests, and acquired a lifelong passion for the mountains of the Pacific Northwest. Grant's father, a banker, suffered setbacks in the Depression and Grant had to give up his plans to leave home for college. $\mathrm{He}$ is still remembered as an outstanding all-around scholar at Reed College in Portland, where he majored in political science and wrote his senior thesis under Charles McKinley on the Social Security Act. While an undergraduate at Reed, Grant met his future wife, Jane Foster, a Yale-educated public health nurse who was briefly in charge of the campus health service.

Grant graduated from Reed in 1937 and went East to begin graduate work in the Harvard government department. Although his supervisor was Carl Friedrich, a political theorist, Grant was heavily influenced in this period by Alvin Hanson, the economist who applied Keynesian theory to the New Deal, and became friendly with the young Paul Samuelson and other graduate students who were impressed with the lessons of Keynes.

During his first year at Harvard, Grant was awarded the Rhodes Scholarship and left for Oxford in the fall of 1938. There he worked primarily with G.D.H. Cole, the great labor historian and theorist of guild socialism. He spent his vacations mountaineering in Europe, and was climbing in Switzerland when war broke out in 1939. The American Rhodes Scholars were immediately called back to Oxford and sent home on a hastily-booked American freighter.

From 1939 to 1941 Grant was enrolled in the government department at Harvard while teaching Economics at Mt. Holyoke Col- lege. $\mathrm{He}$ and Jane, who was working as a nurse at Smith College, were married in 1939.

As US entry into the war grew imminent, Grant moved to Washington seeking government service. His first job was to serve as a writer with the Farm Security Administration-a New Deal agency that Grant believed to be effective in supporting the interests of small and poor farmers, especially in the South. Observing the growing conflict between the FSA and the American Farm Bureau, a government agency serving the more successful farmers, sparked Grant's continuing interest in the role of private constituencies in defining the interests that public agencies can serve, and in the historical tendency of American policymakers to enhance the power of local economic elites. In 1941-42 Grant went to work as an economist for the Office of Price Administration, focusing on issues of war production and rationing.

Grant entered the Navy as an officer in 1943. As a specialist in sonar and radar, he was first assigned to patrol duty off the Pacific Coast, and then to radar picket duty in the East China Sea. On a mission to provide early warning of kamikaze raids, Grant's destroyer was sunk off Okinawa. He suffered lifelong hearing loss as the result of an underwater explosion that occurred while he was attempting to rescue injured shipmates.

In 1946 Grant was discharged from the Navy with the rank of Lieutenant, and went with Jane to live in a partially built cabin in the Cascades wilderness of Stehekin, Washington. There they lived for three years, and during most summers and sabbaticals thereafter until their health finally failed. Grant's and Jane's experiences surviving in the wilderness and fighting to preserve it are richly described in his autobiographical last book, Stehekin, $A$ Valley in Time (1989), which he dedicated to Jane on their 50th anniversary.

In 1949 Grant resumed his graduate work in political science, this time at the University of California, Berkeley. Clark Kerr appointed him in 1950 as a research assistant at the Institute of Industrial Relations where he collaborated with the labor economist Lloyd Fisher. Working under Peter Odegaard during 1951, he wrote his dissertation and first book, The Decline of Agrarian Democracy, in merely nine months-expanding on the work he had done at the Farm Security Agency a decade before. In 1952 he received his Ph.D. and began teaching in the Department of Political Science at Berkeley.

Grant moved to the University of Chicago in 1957, where he rapidly rose to a position of eminence in the profession. In his early years in Chicago he published extensively on the role of major economic groups in the formation of national policy, the labor movement, the conservation movement, and government regulation of business. The year he spent as a visiting professor at Makerere University in Uganda crystallized his interest in the relation between the study of American political institutions and the emerging field of comparative political development studies. Grant played a major role in departmental affairs at the University of Chicago, helping it to achieve national eminence in American and comparative politics and serving as a mentor to a series of graduate students who went on to distinguished careers in the field of American politics. During his eleven years at the University of Chicago, Grant rose rapidly to become Ford Foundation Research Professor and Chair of the Department (1968-69). His significant writings of this period include The Steel Seizure of 1952 (1960), Steel and the Presidency (1963), and The Modern Presidency (1967).

In 1966, Grant published his most important scholarly work, Private Power and American Democracy. This classic volume elegantly synthesized the conclusions of his research on agriculture, labor, steel, and conservation, while placing it in a broad theoretical and historical perspective. In opposition to thinkers like Tocqueville, who had argued for the legitimating role of decentralized private associations in American democracy, Grant demonstrated the tendency of our 
system of interest group representation to turn public power to the service of private ends. This argument challenged the central claim of the dominant school of post-war political science-interest group pluralism-that a government more highly responsive to private interests was for that reason also more "democratic." After nearly thirty years, Private Power stands as one of the landmarks in the debate about the democratic character of the post-New Deal American state, alongside the work of Robert Dahl, Theodore Lowi, and David Truman. It is also among the handful of books in American political science that can be considered a permanent contribution to our civic culture.

In 1969 Grant left the University of Chicago and accepted an appointment in the Politics Board at the University of California, Santa Cruz. He intended to focus his scholarly interest on the emerging field of environmental politics, and he was instrumental in founding the Environmental Studies program at UCSC. His administrative abilities were quickly recognized, however, and he became the first executive vice-chancellor of the campus during 1970-71, and acting chancellor during a difficult period of conflict over the Viet Nam War.

While continuing to write and publish at UC Santa Cruz, Grant devoted an increasing amount of his time to activism and advocacy on environmental issues. He remained convinced that regulatory agencies addressing the environment had been effectively captured by private interests, but he also became concerned that countervailing assertions of a national interest were not sufficiently powerful and broad to capture the fundamental values at stake in preserving wilderness from economic development. Returning to the theme of earlier writings attacking the idea of "multiple use" of wilderness areas, Grant devoted himself increasingly to the stringent protection of pristine forests from exploitation of various kinds. While based in Chicago, Grant had played a major role in creating the Cascades National Park that includes his beloved Stehekin. At Santa Cruz he lent his services as a political scientist and conservationist to organizations devoted to environmental preservation in the Pacific Northwest, and around the world. Grant's name figures prominently in histories of environmental movements and policies of the past fifty years, and his personal papers, now collected at the University of Washington, will be a valuable resource to scholars studying the formation of environmental policy relating to the North Cascades and Alaska.

Grant retired from the University in 1980, and largely withdrew from involvement in the academy to devote himself more fully to his environmental concerns. In 1992 he wrote, "Since retirement I have continued a fight I began while I was in Berkeley, to preserve the magnificent wildlands of the North Cascades, to which I had retreated after my release from the Navy in 1945. I made my own decision early that someone (and it turned out to be me) had to fight to protect that area, the finest in my opinion in the U.S. Well, after 13 years we won two big new wilderness areas, a National Park and two related areas."

Those who knew Grant remember him as a deeply thoughtful and principled man. He was the kind of teacher whose pointed stories would bring students to see things for themselves, and many of his former students still recall apparently casual conversations with Grant that had a permanent impact on their lives. With colleagues Grant was a lively raconteur, hampered in large groups by his loss of hearing, but always ready in personal conversation to engage new ideas with an open mind and the utmost seriousness. Grant was a rare combination of a committed professional, a true intellectual, and a gracious gentleman; his guidance and example helped many younger political scientists with dissenting ideas find a voice and a career.

Grant McConnell is survived by his wife Jane of Bonny Doon, California, his daughter Ann of Ben Lomond, California, his son Jim of Los Angeles, and one granddaughter.

Robert Meister
University of California-Santa Cruz

\section{Bob Cowley Riley}

Bob Cowley Riley, professor emeritus of political science at Ouachita Baptist University, died February 16, 1994. He is survived by his wife, Claudia, and their daughter, Megen. Bob combined his commitment to the academic study of politics with an extensive record of public service and accomplishment that culminated in a brief tenure as governor of Arkansas in 1975.

Bob was born in Little Rock, Arkansas, September 18, 1924. In December 1941, he left high school to enlist in the United States Marine Corps. He served overseas for twenty-four months. On July 21, 1944, he was wounded in action while leading a rifle squad assault on a Japanese machine gun emplacement on Guam. Left for dead, he recovered to face life with severely impaired vision, battered limbs, and constant pain. He persevered with unfailing energy, enthusiasm, and optimism.

$\mathrm{He}$ entered the University of Arkansas in the fall of 1945, earning his B.A. in 1950, his M.A. in 1951, and his Ed.D. in 1957. During these years, he maintained an extraordinarily high level of campus involvement while also serving two terms in the House of Representatives of the Arkansas General Assembly.

He came to Ouachita Baptist College in 1957 as associate professor of history and political science. Under his leadership, political science became a separate department. He developed the curriculum for the departmental major and served as the chair throughout his tenure. Promoted to full professor in 1958, he chaired the division of social sciences from 1960 until 1974.

One of his former students, Jeff Porter, now managing editor of the Batesville Daily Guard, recalled Riley as follows: "With his eye patch and the set of his jaw, he looked like John Wayne's Rooster 